\title{
STUDI PERAN SUBSEKTOR PERIKANAN DALAM PENGEMBANGAN WILAYAH DI KOTA SIBOLGA
}

\author{
Study of Fisheries Subsector in Supporting Regional Development in Sibolga
}

\author{
Muhammad Aspan Panggabean*
}

Staf Dinas Perikanan dan Peternakan, Kota Sibolga, Sumatra Utara

\begin{abstract}
Fisheries subsector is expected to be a strategic sector for future regional development in Sibolga, because this sector is fundamental resources and has renewable character. The purposes of the study are to: (1) identify the fisheries subsector development in Sibolga, (2) analyze the backward and forward linkages of the fisheries subsector economy in Sibolga, (3) explore the perceptions of stakeholders about fisheries subsector development in Sibolga, and (4) formulate the direction of fisheries subsector development priorities in Sibolga. The data analysis used are descriptive analysis, Analytical Hierarcy Process (AHP), and Input-Output (I-O). The results show that the fisheries subsector contributes the highest gross regional domestic product up to $22.86 \%$ and contributes to the total output up to $17.70 \%$. Fisheries still have a potential to explore 123.63 thousand tons in WPP-572 zones, in addition to the exploitation outside the exclusive economic zone. The aquaculture activities (KJA) still have space 1, 276.97 ha to be utilized, located in the district of North Sibolga and Sibolga City. Fishieries subsector in total still has small backward and forward linkage. The low linkages fisheries subsectors provide a low impact on increasing the output of other sectors either direct and indirect linkages to other sectors. The perception of all stakeholders says human resources from fishing activities is a top priority in developing the fisheries subsector, but from the analysis human resource aquaculture should be apriority development in fisheries subsector in Sibolga.
\end{abstract}

Keywords: Fisheries subsector, linkages, regional development, Sibolga

\begin{abstract}
ABSTRAK
Subsektor perikanan diharapkan bisa menjadi sektor strategis bagi pengembangan wilayah Kota Sibolga di masa depan, karena sektor ini merupakan sumber daya fundamental dan termasuk sumberdaya terbarukan. Tujuan penelitian ini adalah untuk: (1) mengidentifikasi pengembangan subsektor perikanan di Sibolga, (2) menganalisis keterkaitan ke belakang dan ke depan (backward and forward linkages) dari ekonomi subsektor perikanan di Sibolga, (3) menggali persepsi pemangku kepentingan tentang pengembangan subsektor perikanan di Sibolga, dan (4) merumuskan arah prioritas pengembangan subsektor perikanan di Sibolga. Analisis data yang digunakan adalah analisis deskriptif, Hierarcy Analytical Process (AHP), dan Input-Output (I-O). Hasilnya menunjukkan bahwa subsektor perikanan menyumbang produk domestik regional bruto tertinggi hingga $22.86 \%$ dan memberikan kontribusi terhadap total output hingga 17.70\%. Perikanan di Sibolga masih memiliki potensi untuk dieksplorasi mencapai 123.63 ribu ton di zona WPP-572, belum termasuk eksploitasi di luar zona ekonomi eksklusif. Keramba Jaring Apung (KJA) masih memiliki ruang seluas 1,276.97 ha untuk dimanfaatkan, terletak di Kecamatan Sibolga Utara dan Kota Sibolga. Subsektor perikanan secara total masih memiliki keterkaitan ke belakang dan ke depan (backward and forward linkages) yang kecil. Rendahnya hubungan subsektor perikanan memberikan dampak yang rendah terhadap peningkatan output sektor lain baik secara langsung maupun tidak langsung terhadap sektor lainnya. Persepsi pemangku kepentingan mengatakan bahwa sumber daya manusia dari kegiatan penangkapan ikan merupakan prioritas utama dalam pengembangan subsektor perikanan, namun dari analisis sumber daya manusia, perikanan budidaya harus menjadi prioritas pengembangan di subsektor perikanan di Sibolga.
\end{abstract}

Kata kunci: Subsektor perikanan, keterkaitan, pembangunan daerah, Sibolga

\section{PENDAHULUAN}

Menurut Peraturan Presiden No. 13 tahun 2012 tentang Rencana Tata Ruang (RTR) Pulau Sumatera, Kota Sibolga ditetapkan sebagai salah satu pusat kegiatan wilayah (PKW) industri pengolahan dan industri jasa hasil perikanan dan juga sebagai kawasan andalan Tapanuli dan sekitarnya yang terhubung dengan akses ke dan dari pelabuhan Sibolga. Dengan kata lain, dengan ketetapan dan dukungan dari Pemerintah Pusat, Kota Sibolga dapat menjadi pusat pertumbuhan yang potensial di wilayah Barat Sumatera, khususnya sebagai pendukung perkembangan wilayah Tapanuli dan sekitarnya.

Kota Sibolga merupakan salah satu sentra produksi ikan di Kawasan Pantai Barat Sumatera. Dari sisi struktur perekonomian berdasarkan distribusi PDRB atas dasar harga konstan tahun 2000 menunjukkan bahwa subsektor perikanan memberikan sumbangan terbesar dalam 
pembentukan PDRB dengan kontribusinya sebesar $23.87 \%$ dari total nilai PDRB Kota Sibolga tahun 2010 (BPS, 2011). Namun demikian, Kota Sibolga masih melakukan impor untuk memenuhi permintaan ikan baik untuk kebutuhan konsumsi penduduk maupun untuk kebutuhan industri. Pada tahun 2010 total impor ikan Kota Sibolga mencapai nilai Rp 12.52 miliar yang terdiri dari Rp 12.47 miliar impor ikan laut dan Rp 47.03 juta untuk ikan tawar. Data impor ini menunjukkan bahwa untuk memenuhi permintaan akhir subsektor perikanan di Kota Sibolga masih tergantung dari daerah luar, yang sebagian untuk konsumsi dan juga untuk dikirim keluar. Khususnya untuk kebutuhan industri cukup besar, impor merupakan salah satu alternative untuk mencukupi kebutuhan, disamping inovasi teknologi penangkapan ikan juga harus disiapkan.

Keberlangsungan subsektor perikanan perlu didukung perencanaan wilayah yang efektif dan efisien. Kajian seksama mengenai perkembangan subsektor ini dilakukan untuk menemukan dan mengenali kondisi dan potensi yang ada baik dari sisi fisik maupun dari para pelaku usaha tersebut, sehingga dapat menghasilkan arahan perencanaan pembangunan. Dengan munculnya arahan ini diharapkan dapat memacu perkembangan perekonomian daerah yang pada akhirnya dapat meningkatkan peluang kerja serta kesejahteraan masyarakat di Kota Sibolga.

Tujuan penelitian ini adalah: (1) mengidentifikasi pengembangan subsektor perikanan di Kota Sibolga; (2) menganalisis peran subsektor perikanan dan keterkaitan ke depan dan ke belakang (forward and backward) dalam perekonomian Kota Sibolga; (3) menggali persepsi stakeholders terhadap pembangunan subsektor perikanan di Kota Sibolga; (4) merumuskan arahan pembangunan subsektor perikanan di Kota Sibolga.

\section{BAHAN DAN METODE}

Penelitian dilakukan di Kota Sibolga Provinsi Sumatera Utara mulai bulan Juni 2012 sampai bulan Oktober 2012. Data yang digunakan terdiri atas data primer dan data sekunder. Data primer khususnya untuk persepsi pengembangan perikanan diperoleh dari wawancara dan pengisian kuesioner kepada responden yang merupakan stakeholder yang terlibat dalam pembangunan subsektor perikanan di Kota Sibolga serta wawancara terkait pengumpulan data semi survei untuk membangun tabel input-output Kota Sibolga tahun 2010 yang berisi aliran hasil perikanan ke dalam dan keluar Sibolga. Data sekunder yang digunakan berupa data statistik perikanan, tabel I-O Provinsi Sumatera Utara tahun 2003 dan data PDRB.

Penelitian ini menggunakan tiga metode analisis yaitu :

\section{(1) Analisis Deskriptif}

Analisis deskriptif dilakukan untuk mengetahui kondisi sektor perikanan, potensi pengembangannya dan peranannya dalam perekonomian wilayah. Kondisi aktual subsektor perikanan dianalisis dari data produksi hasil perikanan, sarana dan prasarana pendukung, serta datadata lain yang mencerminkan keragaan data subsektor perikanan di Kota Sibolga.

\section{(2) Analisis Input-Output (I-O)}

Analisis Input-Output (I-O) digunakan untuk mengetahui peranan subsektor perikanan dalam perekonomian wilayah yang meliputi keterkaitan sektoral dan multiplier effect. Dengan analisis tersebut dapat diketahui keunggulan suatu sektor dalam aktivitas perekonomian, yang merupakan salah satu hal yang perlu dipertimbangkan dalam rangka pengembangan wilayah (Daryanto dan Hafizrianda, 2010). Tabel I-O Kota Sibolga tahun 2010 diperoleh melalui metode RAS berdasarkan Tabel I-O provinsi Sumatera Utara tahun 2003 dengan subsektor perikanan dipecah menjadi dua kegiatan yaitu perikanan tangkap dan perikanan budidaya yang nilainya didapatkan melalui teknik survei khusus subsektor perikanan. Tahapan update tabel I-O semi survei dapat dlihat pada Gambar 1.

\section{(3) Analytical Hierarcy Process (AHP)}

AHP adalah model analisis data yang digunakan untuk menelaah kebijakan (Saaty, 2008). Stakeholders yang diminta pendapatnya adalah Dewan Perwakilan Rakyat Daerah Kota Sibolga, Badan Perencanaan Pembangunan Daerah Kota Sibolga, Dinas Kelautan Perikanan dan Peternakan Kota Sibolga, pihak swasta, masyarakat nelayan, dan lembaga swadaya masyarakat. Data yang ditanyakan memiliki tujuan untuk pembangunan sektor perikanan yang dipengaruhi oleh beberapa hal antara lain modal, pasar, sarana prasarana, sumberdaya manusia dan sumberdaya ikan.

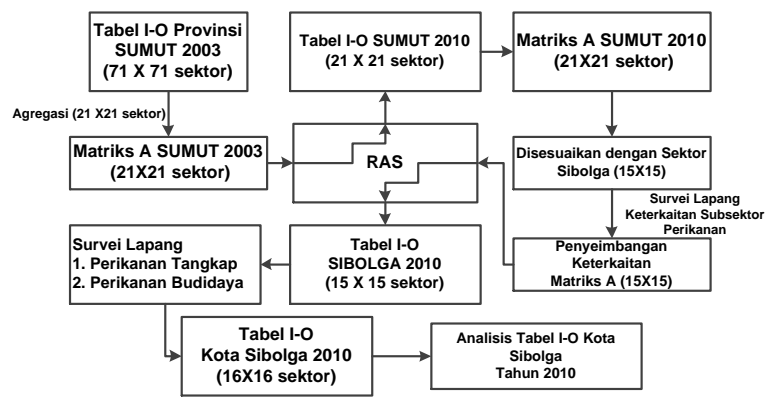

Gambar 1. Tahapan metode RAS update tabel I-O Kota Sibolga semi survei.

\section{HASIL DAN PEMBAHASAN}

\section{Kondisi dan Potensi Subsektor Perikanan}

Usaha perikanan tangkap menghasilkan produksi sebesar 99.99\% dari total produksi perikanan (dalam satuan volume) di Kota Sibolga pada tahun 2010 sedangkan sisanya diperoleh melalui kegiatan budidaya. Produksi perikanan tangkap merupakan hasil aktivitas yang dilakukan dilaut. Kegiatan perikanan budidaya aktivitasnya dilakukan di laut berupa keramba jaring apung (KJA) dan di darat berupa kolam air tawar.

Berdasarkan data peta keragaan perikanan tangkap tahun 2010 (KKP, 2011a) mencatat estimasi potensi sumber daya ikan di zona WPP-572 berdasarkan teknologi yang ada mencapai 565.30 ribu ton per tahunnya (Tabel 1). Apabila dihitung dari data hasil tangkapan ikan yang didaratkan pada zona WPP 572 tersebut baru mencapai nilai produksi sebesar 441.67 ribu ton (KKP, 2011b), ini 
artinya masih ada peluang pemanfaatan pengelolaan sumberdaya ikan sebesar 123.63 ribu ton. Di samping itu wilayah perairan pantai barat Sumatera yang langsung berhadapan dengan Samudera Hindia memberikan peluang yang cukup besar bagi nelayan di Kota Sibolga untuk lebih berekspansi lebih jauh dalam mengeksploitasi ikan tangkap di luar Zona Ekonomi Eksklusif untuk meningkatkan produksinya.

Tabel 1. Estimasi potensi sumber daya ikan di zona WPP-572

\begin{tabular}{clc}
\hline No & Kelompok Sumber Daya Ikan & Potensi (ribu ton $/$ tahun $^{-1}$ ) \\
\hline 1 & Ikan Pelagis Besar & 164.9 \\
2 & Ikan Pelagis Kecil & 315.1 \\
3 & Ikan Demersal & 68.1 \\
4 & Udang Penaeid & 4.9 \\
5 & Ikan Karang Konsumsi & 8.9 \\
6 & Lobster & 0.7 \\
7 & Cumi-cumi & 1.8 \\
\hline \multicolumn{2}{c}{ Jumlah } \\
\hline
\end{tabular}

Wilayah pantai barat Sumatera merupakan bagian laut Indonesia yang stategis karena langsung berhadapan dengan laut lepas yaitu Samudera Hindia. Potensi yang cukup tinggi memancing kapal-kapal asing masuk masuk dan melakukan penangkapan ikan. Dengan teknologi penangkapan yang dibenahi mesin kapal yang kuat, kapalkapal asing ini secara cepat dan langsung melarikan diri ketika tertangkap dan dikejar oleh angkatan laut Indonesia (Ferdi dan Delfiyanti, 2010).

Menurut Sparre dan Vanema (1999) aspek yang mengakibatkan produksi ikan rendah adalah kurangnya teknologi penangkapan ikan. Hal yang sama juga dijelaskan oleh Ferdi dan Delfiyanti (2010), bahwa kemampuan teknologi yang dimiliki armada penangkapan ikan asing yang masuk ke wilayah perairan pantai barat Sumatera ini perlu diadopsi dan dikembangkan oleh nelayan di kota Sibolga sehingga dapat meningkatkan produktivitas perikanan. Disamping itu, Stobutzki et al. (2006) dan Widodo dan Suadi (2006), mengatakan bahwa rendahnya produktivitas hasil perikanan masih disebabkan oleh tingkat pemanfaatan hasil perikanan yang relatif tidak mengalami perkembangan.

Untuk komoditas budidaya ikan laut yang dilakukan oleh masyarakat melalui KJA menunjukkan peluang pengembangan yang cukup menjanjikan. Hal ini dibuktikan bahwa hasil produksi ikan hampir $100 \%$ di ekspor keluar Kota Sibolga dalam kondisi hidup. Komoditas ikan yang dibudidayakan berupa ikan kerapu, kakap, baronang, kuwe dan kepiting. Nilai jual produk ikan ini cukup tinggi bila dibandingkan dengan nilai jual ikan konsumsi lokal yang dijual di pasar. Namun kendala yang dihadapi oleh masyarakat pembudidaya adalah pemahaman teknis budidaya ikan yang minim serta keterbatasan modal usaha. Bila dilihat dari sisi pemanfaatan ruang, pemanfaatan perairan laut hanya digunakan oleh empat masyarakat pembudidaya dengan pemanfaatan ruang baru sekitar 0.0159 ha sedangkan potensi pemanfaatan ruang hingga ke arah laut ada sekitar 1,626.99 ha, sehingga produktivitas KJA ini masih sangat rendah.

Disamping pengembangan KJA, perikanan darat juga memiliki peluang untuk berkembang. Ini dibuktikan dari masih tingginya kebutuhan impor ikan air tawar yang masuk ke pasar-pasar yang di Kota Sibolga. Untuk memenuhi kebutuhan ikan air tawar berupa ikan mas, ikan lele, ikan nila dan ikan mujahir, pedagang harus memasukkan rata-rata $500 \mathrm{~kg}$ tersebut setiap minggunya.

\section{Peranan Subsektor Perikanan dalam Perekonomian Kota Sibolga}

\section{Struktur Perekonomian Kota Sibolga Tahun 2010.}

Salah satu indikator untuk menggambarkan perekonomian wilayah adalah PDRB. Besarnya peran subsektor perikanan dalam berkontribusi terhadap PDRB atas dasar harga berlaku mencapai $22.87 \%$ dari total PDRB di Kota Sibolga tahun 2010 atau menempati peringkat tertinggi.

Tabel 2. Struktur perekonomian Kota Sibolga berdasarkan tabel I-O

\begin{tabular}{|c|c|c|c|}
\hline No. & Uraian & $\begin{array}{c}\text { Jumlah } \\
\text { (Juta Rupiah) }\end{array}$ & $\begin{array}{c}\text { Persentase } \\
(\%) \\
\end{array}$ \\
\hline & Struktur Output & & \\
\hline 1 & Jumlah Permintaan Antara & $689,639.00$ & 29.58 \\
\hline 2 & Jumlah Permintaan Akhir & $1,641,980.71$ & 70.42 \\
\hline \multirow[t]{2}{*}{3} & Total Output & $2,331,619.71$ & 100.00 \\
\hline & Struktur Input & & \\
\hline 4 & Jumlah Input Antara & $689,639.00$ & \\
\hline \multirow[t]{5}{*}{5} & $\begin{array}{l}\text { Jumlah Input Primer/Nilai } \\
\text { Tambah Bruto }\end{array}$ & $1,543,776.71$ & 100.00 \\
\hline & - Upah dan Gaji & $506,997.89$ & 32.84 \\
\hline & - Surplus Usaha & $885,851.95$ & 57.38 \\
\hline & - Penyusutan & $119,863.87$ & 7.76 \\
\hline & - Pajak Tak Langsung & $31,062.99$ & 2.01 \\
\hline
\end{tabular}

Selain melalui struktur PDRB, peranan sektor ekonomi dapat diketahui melalui analisis I-O Kota Sibolga 2010. Berdasarkan analisis terhadap struktur output diketahui bahwa dari total output $29.58 \%$ merupakan permintaan antara dan $70.42 \%$ adalah permintaan akhir (Tabel 2). Struktur Tabel I-O dengan nilai total output lebih banyak dialokasikan sebagai permintaan akhir,yang menunjukkan bahwa output yang ada cenderung digunakan untuk konsumsi dan ekspor (final demand) daripada digunakan untuk transaksi antar sektor dalam proses produksi dalam wilayah. Aktivitas barang dan jasa oleh sektor-sektor ekonomi wilayah yang memanfaatkan input antara sebagai input produksi relatif rendah.

\section{Keterkaitan Sektoral.}

Keterkaitan langsung ke belakang atau Direct Backward Linkage (DBL) menunjukkan akibat suatu sektor tertentu terhadap sektor-sektor yang menyediakan input bagi sektor tersebut secara langsung per unit kenaikan permintaan akhir. Keterkaitan langsung ke belakang sektor-sektor perekonomian ditampilkan pada Gambar 2a. Keterkaitan langsung ke depan atau Direct Forward Linkage (DFL) menunjukkan akibat suatu sektor tertentu terhadap sektor-sektor yang menggunakan sebagian output tersebut secara langsung per unit kenaikan permintaan akhir (Gambar 2b).

Berdasarkan Gambar 2 terlihat kedua subsektor perikanan memiliki nilai indeks keterkaitan yang masih rendah, yang berarti subsektor perikanan memiliki peran yang masih rendah untuk menggerakkan sektor-sektor ekonomi wilayah secara langsung, dimana pemanfaatan input antara dari subsektor perikanan ini masih kecil dan subsektor perikanan ini lebih cenderung memenuhi permintaan akhir daripada permintaan antara. 


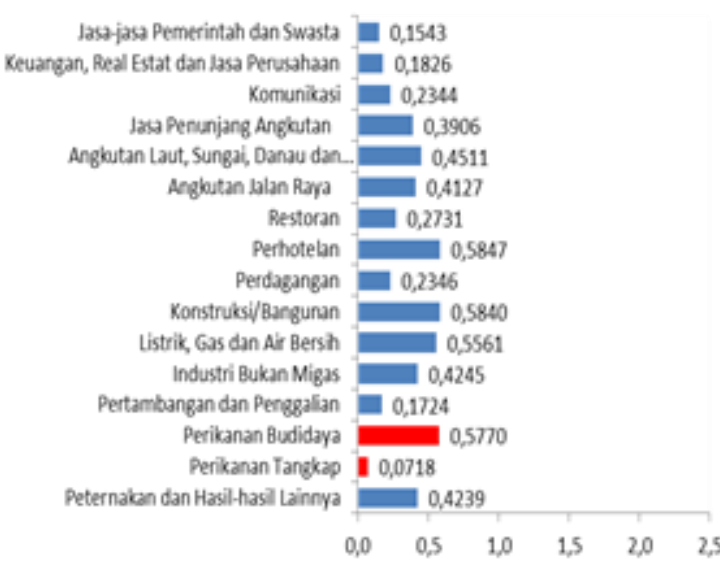

(a) Keterkaitan ke Belakang

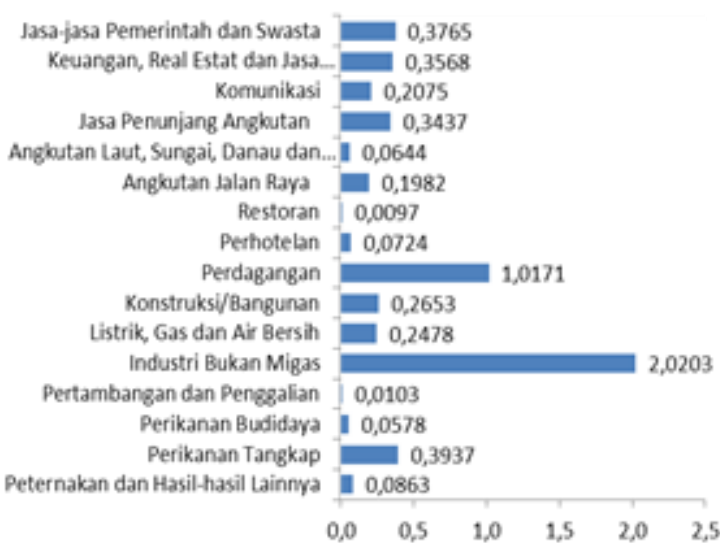

(b) Keterkaitan ke Depan

Gambar 2. Keterkaitan Langsung sektor-sektor perekonomian

Tabel 3. Nilai multiplier effect, Indeks Daya Penyebaran (IDP) dan Indeks Derajat Kepekaan(IDK) subsektor perikanan

\begin{tabular}{|c|c|c|c|c|c|c|}
\hline \multirow{2}{*}{ No } & \multirow{2}{*}{ Kegiatan Sektor } & \multicolumn{3}{|c|}{ Multiplier Effect } & \multirow{2}{*}{ IDP } & \multirow{2}{*}{ IDK } \\
\hline & & Output & Nilai Tambah Bruto & Pendapatan & & \\
\hline 1 & Perikanan Tangkap & 1.10 & 1.08 & 1.08 & 0.89 & 0.94 \\
\hline \multirow[t]{2}{*}{2} & Perikanan Budidaya & 1.72 & 2.34 & 14.43 & 0.89 & 1.66 \\
\hline & Rata-rata & 1.41 & 1.71 & 5.76 & & \\
\hline
\end{tabular}

Tabel 3 menunjukkan bahwa kegiatan perikanan budidaya memiliki nilai multiplier effect pendapatan, output dan Nilai Tambah Bruto (NTB) tertinggi. Potensi ini memberikan peluang peningkatan angka penggandaan yang cukup tinggi untuk memacu peningkatan output sektor-sektor ekonomi lain di Kota Sibolga. Kegiatan perikanan budidaya ini juga mampu meningkatkan angka pendapatan seluruh sektor-sektor ekonomi lainnya secara total sebesar 14.43 kali per peningkatan output kegiatan perikanan budidaya.

Untuk nilai IDP dari subsektor perikanan, nilai tertinggi dimiliki dari kegiatan perikanan budidaya sebesar 1.89. Sedangkan untuk nilai IDK sendiri dari kedua kegiatan subsektor perikanan di Kota Sibolga masih cukup rendah. Nilai IDK tertinggi berada pada kegiatan perikanan budidaya dengan nilai sebesar 1.66. Nilai derajat penyebaran dan derajat kepekaan yang tinggi suatu sektor (>1) artinya sektor tersebut memiliki kekuatan dalam menggerakkan sektor-sektor ekonomi lain dalam wilayah.

Dari hasil analisis Input-Output ini, terlihat bahwa kegiatan perikanan budidaya memiliki peluang pengembangan dibandingkan dengan kegiatan perikanan tangkap. Dari sisi pendapatan, kegiatan perikanan budidaya memiliki nilai penggandaan (multiplier) yang tinggi bila dibandingkan dengan kegiatan perikanan tangkap. Begitu juga dalam hal pembentukan stuktur output maupun pembentuk NTB, kegiatan perikanan budidaya juga lebih unggul dibandingkan dengan kegiatan perikanan tangkap.

\section{Isu Sentral Pembangunan Sektor Perikanan}

Untuk menentukan prioritas pembangunan pada subsektor perikanan di Kota Sibolga dilakukan dengan cara penilaian skor atas jawaban yang didapatkan melalui Analytic Hierarchy Process (AHP). Stakeholders yang dilibatkan dalam pengisian AHP ini dianggap cukup mewakili karena mengerti permasalahan, sebagai pelaku dan pembuat keputusan yang memiliki informasi dan memahami permasalahan perikanan.

Dari hasil analisis AHP terdapat perbedaan persepsi masing-masing stakeholder untuk skala prioritas pengembangan subsektor perikanan. Ini menunjukkan masih kurangnya pemahaman konsep pembangunan dan sosialisasi perencanaan pembangunan khususnya subsektor perikanan di Kota Sibolga. Hasil penjaringan persepsi seluruh stakeholder dapat dilihat di Gambar 3.

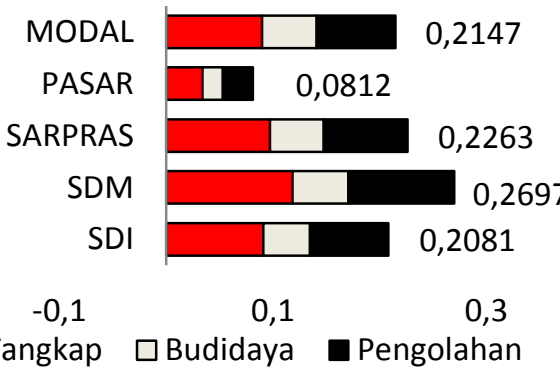

(a)

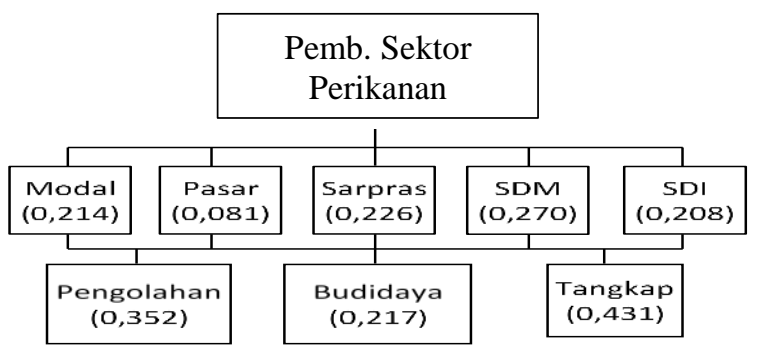

(b)

Gambar 3. (a) Pemilihan alternatif pembangunan subsektor perikanan menurut persepsi seluruh stakeholders, (b) Hasil AHP penentuan prioritas pengembangan subsektor perikanan menurut persepsi seluruh stakeholders. 
Gambar 3 menunjukkan bahwa persepsi seluruh stakeholders dalam pengembangan subsektor perikanan yang didasarkan pada lima faktor yang berpengaruh dalam penentuan kegiatan pembangunan perikanan, faktor Sumberdaya Manusia (SDM) dari kegiatan perikanan tangkap menjadi prioritas pengembangannya di Kota Sibolga. Kualitas SDM pada kegiatan perikanan tangkap perlu ditingkatkan dengan jalan melakukan pelatihan penggunaan teknologi pendukung alat tangkap kepada nelayan. Dengan meningkatnya keterampilan pemanfaatan teknologi penangkapan yang mutahir diharapkan lebih meningkatkan produktivitas perikanan tangkap.

Hasil persepsi ini bila dibandingkan dari analisis potensi sektoral yang ada, prioritas pengembangan subsektor perikanan harus lebih fokus dilakukan terhadap optimalisasi pengembangan kegitan perikanan budidaya KJA dengan pemanfaatan potensi ruang yang masih cukup besar. Hal ini dikuatkan hasil analisis I-O yang berdampak peningkatan multiplier effect, NTB dan pendapatan yang cukup tinggi dibandingkan dengan kegiatan perikanan tangkap. Dukungan peningkatan SDM dan penguatan modal usaha menjadi aspek yang perlu diperhatikan. Secara keruangan, pemanfaatan ruang laut masih cukup luas dijadikan sebagai kawasan budidaya untuk meningkatkan produktivitasnya.

\section{Arahan Lokasi Pengembangan Sektor Perikanan}

Dengan keterbatasan luasan wilayah administrasi yang dimiliki Kota Sibolga, mengharuskan pemerintah untuk melakukan penataan ruang dengan efektif, efisien dan produktif, dengan harapan arahan lokasi pembangunan subsektor perikanan nantinya mampu meningkatkan produktivitas dengan tetap mempertimbangkan aspek keberlanjutan. Dari pengumpulan persepsi stakeholder yang ada, diambil rata-rata keterwakilan pendapatnya yang kemudian dituangkan ke dalam arahan lokasi pengembangan subsektor perikanan dapat dilihat pada Gambar 4.

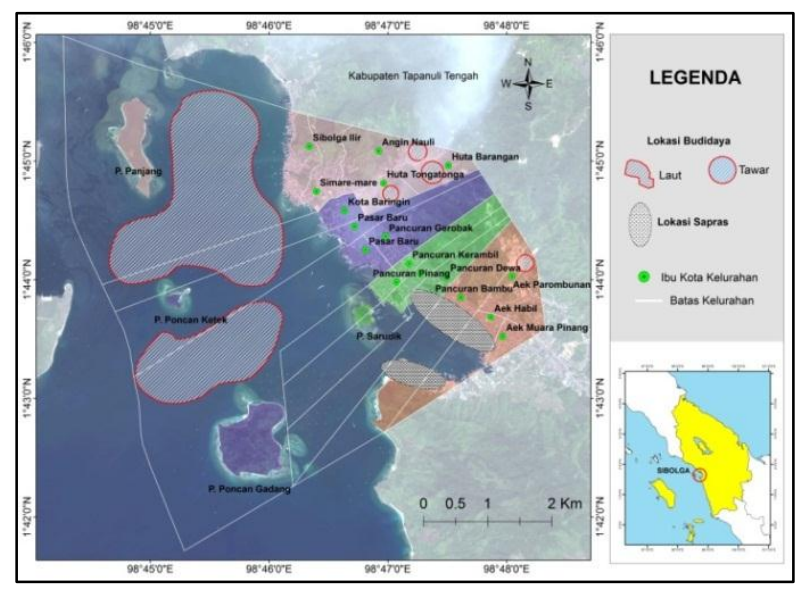

Gambar 4. Arahan pemanfaatan ruang Kota Sibolga

Dari hasil tabulasi kuesioner, enam stakeholder sepakat memilih wilayah laut pada Kecamatan Sibolga Utara dan Sibolga Kota sebagai lokasi pengembangan kegiatan budidaya laut. Lokasi budidaya air tawar yang tepat adalah Kelurahan Angin Nauli, Huta Tongatonga dan Aek Parombunan menjadi lokasi yang tepat. Untuk lokasi pengembangan sarana dan prasarana perikanan, Kecamatan Sibolga Sambas dan Sibolga Selatan. Pengembangan sarana dan prasarana perikanan adalah ketersediaan tempat pelelangan ikan dan pengisian bahan bakar serta sarana prasarana pendukung lainnya. Dari penetapan lokasi-lokasi ini diharapkan dapat menjadi bahan pertimbangan pemerintah daerah dalam penyusunan rencana tata ruang wilayah.

\section{Bahasan Umum}

Keterpaduan sektoral, spasial, serta keterpaduan antar pelaku pembangunan dalam wilayah perlu disinergikan dalam proses pengembangan wilayah. Keterpaduan sektoral menuntut adanya keterkaitan fungsional yang sinergis antar sektor pembangunan, sehingga setiap sektor kegiatan pembangunan dalam kelembagaan sektoral dilaksanakan dalam kerangka pembangunan wilayah. Salah satu bentuk terjadinya kegagalan pemerintah yang umum adalah kegagalan menciptakan keterpaduan sektoral yang sinergis didalam kerangka pembangunan wilayah (Rustiadi et al., 2011).

Dari struktur perekonomian, subsektor perikanan memberikan kontribusi penyumbang PDRB tertinggi dan pembentuk struktur output terbesar ke-2 bila dibandingkan dengan sektor-sektor ekonomi lainnya (setelah sektor perdagangan). Tetapi dari sisi keterkaitan subsektor perikanan terhadap sektor-sektor ekonomi lainnya masih cukup lemah. Subsektor perikanan masih belum berpengaruh besar dalam menggerakkan sektor-sektor domestik yang ada di Kota Sibolga secara langsung (terlihat dari sumbangan DFL dan DBL yang masih rendah).

Dalam hal meningkatkan maupun memunculkan keterkaitan langsung pada akhirnya juga akan lebih meningkatkan keterkaitan secara tidak langsung sektorsektor ekonomi lain di Kota Sibolga. Untuk itu pembangunan industri-industri pengolahan ikan yang hingga saat ini masih belum ada untuk skala besar menjadi perhatian pemerintah daerah untuk dikembangkan. Dengan berkembangnya industri-industri ini, akan menciptakan keterkaitan sektor-sektor yang baru yang dapat meningkatkan keterkaitan sektor-sektor ekonomi yang telah ada sebelumnya baik langsung maupun tidak langsung terhadap subsektor perikanan (Gambar 5).

Untuk arahan alokasi pemanfaatan ruang, pemerintah daerah harus melibatkan masyarakat untuk turut serta berpartisipasi dalam menyusun rencana tata ruang sehingga tercipta penyamaan persepsi terhadap arahan pembangunan daerah. Seperti yang diamanatkan Undang-Undang Tata Ruang No. 26 tahun 2008 bahwa dalam proses perencanaan rencana tata ruang wilayah, perlu partisipasi masyarakat yang terlibat dan bersifat transparan terbuka untuk publik. Dokumen rencana tata ruang yang sifatnya sebagai dokumen publik, diisyaratkan juga dalam Undang-Undang Keterbukaan Informasi Publik No. 14 tahun 2008.

Upaya menciptakan kondisi pengembangan subsektor perikanan perlu kerjasama stakeholder dalam hal penyamaan persepsi penentuan skala prioritas pembangunan di kota Sibolga, sehingga tujuan pembangunan wilayah dapat tercapai untuk mewujudkan kesejahteraan masyarakat di wilayah tersebut. 


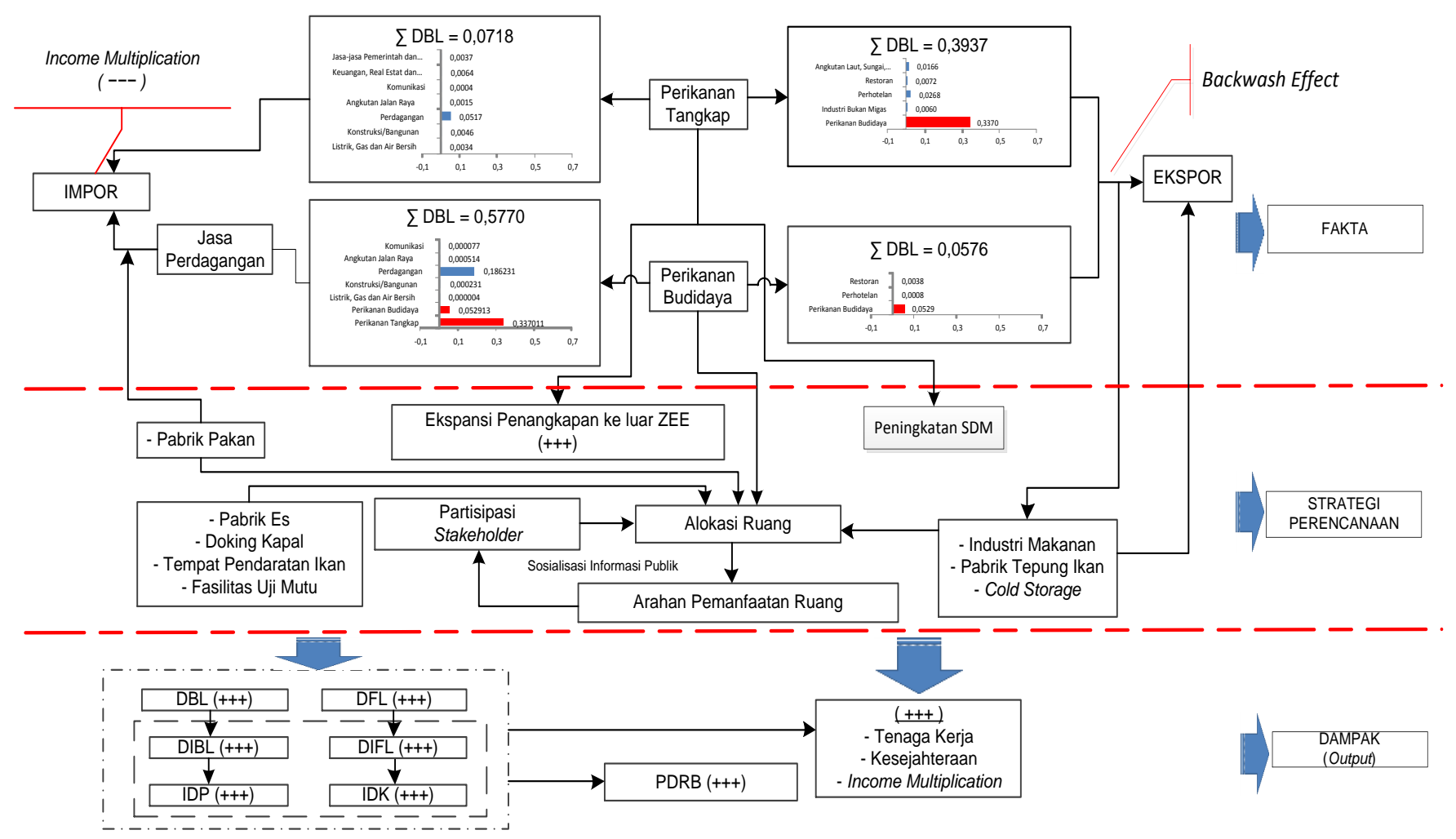

Gambar 5. Sintesis data spasial, sektoral dan partisipatif subsektor perikanan

Perbedaan persepsi yang berbeda-beda dalam hal penentuan skala priorotas pembangunan, akan berdampak negatif terhadap pengembangan subsektor perikanan di Kota Sibolga nantinya. Kajian ilmiah perlu menjadi dasar penentuan skala prioritas penganggaran sektor ekonomi, dengan kajian ini diharapkan dapat lebih mengoptimalkan sasaran pembangunan daerah.

\section{SIMPULAN}

Berdasarkan hasil analisis dan pembahasan yang dilakukan serta kaitannya dengan tujuan penelitian maka dapat disimpulkan hal-hal sebagai berikut:

1. Peningkatan produksi perikanan tangkap masih memiliki peluang pemanfaatan pada zona WPP-572 dengan potensi 123.63 ribu ton tahun ${ }^{-1}$, disamping kegiatan eksplotasi di luar ZEE, dan untuk kegiatan perikanan budidaya (KJA), ruang yang masih tersedia sebesar 1,276.97 ha yang berada di Kecamatan Sibolga Utara dan Sibolga.

2. Subsektor perikanan secara total masih memiliki keterkaitan langsung ke depan dan ke belakang yang kecil. Dengan minimnya keterkaitan ini, subsektor perikanan memberikan pengaruh yang rendah terhadap peningkatan output sektor lainnya secara langsung, sehingga juga berdampak rendah terhadap keterkaitan tidak langsung sektor-sektor lainnya. Namun demikian perikanan budidaya memiliki nilai multiplier effect yang lebih tinggi bila dibandingkan dengan perikanan tangkap. Nilai penggandaan pendapatan yang dihasilkan dari kegiatan perikanan budidaya ini mencapai 14.43 yang merupakan nilai tertinggi dari seluruh sektor ekonomi yang ada di Kota Sibolga.
3. Penetapan skala prioritas pengembangan subsektor perikanan berdasarkan hasil penjaringan seluruh stakeholder tidak menunjukkan perbedaan nyata antara faktor SDM, sarana dan prasarana, dan modal. Seluruh stakeholder menganggap ketiga faktor tersebut perlu diprioritaskan pengembangannya, tetapi dari hasil analisis seluruh stakeholder, prioritas tertinggi terpilih adalah peningkatan SDM pada kegiatan perikanan tangkap. Berbeda dari fakta hasil analisis bahwa pengembangan kegiatan perikanan budidaya dari sisi peningkatan kualitas SDM selayaknya menjadi sorotan skala prioritas pembangunannya di Kota Sibolga karena kegiatan ini memiliki dampak penggandaan secara total output dan pendapatan yang cukup tinggi.

4. Arahan pengembangan untuk pembangunan subsektor perikanan adalah (1) perikanan budidaya, khususnya KJA menjadi prioritas untuk pengembangan karena pembentukan nilai penggandaan dan pendapatan lebih tinggi bila dibandingkan dengan perikanan tangkap. Untuk arahan lokasi pengembangan perikanan budidaya, pemanfaatan ruang yang potensial berada di perairan laut Kecamatan Sibolga Utara dan Sibolga Kota; (2) untuk meningkatkan perekonomian regional Kota Sibolga, sektor-sektor baru perlu dikembangkan karena hal ini akan berdampak peningkatan keterkaitan sektoral langsung maupun tidak langsung terhadap subsektor perikanan.

\section{DAFTAR PUSTAKA}

[BPS] Badan Pusat Statistik Provinsi Sumatera Utara. 2004. Tabel Input Output Provinsi Sumatera Utara Tahun 2003 (updating). Badan Pusat Statistik Provinsi Sumatera Utara. Medan. 
[BPS] Badan Pusat Statistik Kota Sibolga. 2011. Sibolga dalam Angka. Badan Pusat Statistik Kota Sibolga. Sibolga.

[KKP] Kementerian Kelautan Perikanan. 2011a. Peta Keragaan Perikanan Tangkap di Wilayah Pengelolaan Perikanan Republik Indonesia (WPPRI). KKP Dirjen Perikanan tangkap. Jakarta.

[KKP] Kementerian Kelautan Perikanan. 2011b. Statistik Perikanan Tangkap Indonesia 2010. KKP Dirjen Perikanan tangkap. Jakarta.

Daryanto, A. dan Y. Hafizrianda. 2010. Analisis InputOutput dan Social Accounting Matrix untuk Pembangunan Ekonomi Daerah. IPB Press., Bogor.

Dinas Kelautan Perikanan dan Peternakan. 2011. Statistik Perikanan dan Peternakan Kota Sibolga. DKPPSibolga. Sibolga.

Ferdi dan Defrianti. 2010. Penanggulangan terhadap kegiatan illegal fishing oleh kapal-kapal penangkap ikan asing di wilayah pantai barat Sumatera. Jurnal Hukum, 17: 1-21.
Rustiadi, E., S. Saefulhakim dan D.R. Panuju. 2011. Perencanaan dan Pengembangan Wilayah. Crestpent Press dan Yayasan Obor Indonesia, Jakarta.

Saaty, T.L. 2008. Making decisions in hierarchic and network systems. Int. J. Applied Decision Sciences, 1: 24-79.

Sparre, P. dan S.C. Venema. 1999. Introduksi Pengkajian Stok Ikan Tropis. Kerjasama Organisasi Pangan Perserikatan Bangsa-Bangsa dengan Pusat Penelitian dan Pengembangan Perikanan. Jakarta. Hal. 303-324.

Stobutzki, I.C., G.T. Silvestre, and L.R. Garces. 2006. Key issues in coastal fisheries in South and Southeast Asia, outcomes of a regional initiative. J. Fisheries Research, 78: 109-118.

Widodo, J. dan Suadi. 2006. Pengelolaan Sumberdaya Perikanan Laut. Gadjah Mada University Press. Yogyakarta. 